\title{
Inotuzumab Ozogamicin Monotherapy as an Outpatient Salvage Treatment in Relapsed Refractory B-Cell Acute Lymphoblastic Leukemia: Compassionate Access
}

\author{
Vivek S. Radhakrishnan ${ }^{1, \odot ~ K e t a n ~ M o d a k ~}{ }^{1}$ Saurabh J. Bhave ${ }^{1}$ Jeevan Kumar ${ }^{1}$ Mita Roychowdhury ${ }^{1}$ \\ Manik Ghosh ${ }^{1}$ Mayur Parihar ${ }^{2}$ Neeraj Arora ${ }^{2}$ Deepak K. Mishra ${ }^{2}$ Reena Nair ${ }^{1, \odot ~ M a m m e n ~ C h a n d y, ~}$ \\ ${ }^{1}$ Clinical Hematology Oncology and Hematopoietic Cell \\ Transplantation, Tata Medical Center, Kolkata, West Bengal, India \\ 2 Laboratory Hematology, Cytogenetics, and Molecular Pathology, \\ Tata Medical Center, Kolkata, West Bengal, India \\ Address for correspondence Vivek S. Radhakrishnan, MD, DM, \\ MSc, PDF Clinical Hematology Oncology and Hematopoietic \\ Cell Transplantation, Tata Medical Center, 14, MAR(EW), \\ Newtown, Rajarhat, Kolkata, West Bengal 700160, India \\ (e-mail: drvivekradhakrishnan@yahoo.com).
}

\begin{abstract}
Keywords

- inotuzumab ozogamicin

- minimal residual disease

- relapsed refractory B-cell ALL

-immunotherapy

- targeted therapy

- hematopoietic cell transplantation

Relapsed and refractory (RR) acute lymphoblastic leukemia (ALL) poses unique and difficult challenges to a practicing clinician in India where access to novel immunotherapies is limited. Between 2017 and 2020, eight patients with B-cell ALL at our center received inotuzumab ozogamicin (IO) monotherapy on compassionate access, as salvage therapy after at least two lines of conventional therapy failure, and most often as outpatient infusion. Eight patients (21-60 years, three females) received IO. Three patients had morphologic relapse and five patients reported persistent measurable residual disease (MRD). The best response on IO therapy achieved was negative MRD in six of seven patients and complete response (CR) with persistent MRD in one. One patient died (intracranial hemorrhage) before completion of first cycle. All responding patients were transplant eligible and four patients $(57 \%)$ underwent allogeneic hematopoietic cell transplantation (Allo-HCT). Median follow-up of this cohort is 9 months (4-29.6 months), four patients (57\%) are alive as stable with negative MRD. No significant infusion reactions occurred during therapy. Three patients developed grades III and IV neutropenia, two patients showed grade III transaminitis, and two patients developed post-HCT severe sinusoidal obstruction syndrome (SOS). $\mathrm{IO}$ is a feasible outpatient based salvage therapy to improve the remission status in RR B-cell ALL.
\end{abstract}

\section{Introduction}

Adult acute lymphoblastic leukemia (ALL) comprise around $20 \%$ of all cases of ALL with an incidence of approximately 1.6 per $1,00,000 .{ }^{1}$ Initial response rates are around 60 to $90 \%$; however, only 30 to $50 \%$ maintained

DOI https://doi.org/ $10.1055 / \mathrm{s}-0041-1731860$ ISSN 0971-5851 long-term disease-free survival. ${ }^{2,3}$ Salvage regimens with conventional chemotherapy for relapsed-refractory $(R / R)$ B-cell ALL yield a complete remission (CR) rate of $40 \%$ in first salvage and 10 to $20 \%$ in second salvage and beyond. ${ }^{3,4}$ With low CR rates, only a few patients (5-20\%) undergo allogeneic hematopoietic cell transplantation (Allo-HCT) ${ }^{4-6}$ In the 
developed world, novel therapies are changing outcomes in $\mathrm{R} / \mathrm{R}$ B-cell ALL and include antibody-drug conjugates (inotuzumab ozogamicin [IO]), bispecific antibodies (blinatumomab), and chimeric antigen receptor T-cell therapy (tisagenlecleucel). ${ }^{7}$ At the time of manuscript preparation, these drugs are not licensed in India.

IO is a humanized monoclonal antibody conjugated to calicheamicin directed against CD22 receptor and approved for use in R/R B-cell ALL based on results of INO-VATE study. ${ }^{8}$ CD22 is expressed in more than 90\% of B-cell ALL. ${ }^{9}$ Published data have shown better outcomes with IO as salvage regimen pre-HCT, compared with standard chemotherapy (CR: 80.7 vs. $33.3 \%$, respectively, $p<0.0001$ ). ${ }^{10}$ Around 43 to $47 \%$ patients on IO proceeded to $\mathrm{HCT}^{8,10}$ IO is relatively safe and well tolerated, with a manageable toxicity profile. ${ }^{11}$ Reports of sinusoidal obstruction syndrome (SOS) associated with IO is a concern in those undergoing HCT and with experience, recommendations exist for appropriate use today. ${ }^{12}$ We present an audit of IO monotherapy (obtained through a compassionate access program) and its outcomes in R/R B-cell ALL, an initial experience from a tertiary care cancer center.

\section{Materials and Methods}

Between 2017 and 2020, adult patients with R/R B-cell ALL who failed at least two prior lines of therapy (including the persistence of measurable residual disease [MRD]) received IO monotherapy under a compassionate use program for India, from Pfizer. Compassionate access program is available from established and reputed pharmaceutical companies on selected innovator drugs which are licensed by regulatory agencies abroad, and not yet licensed for sale in India by the Indian Government's drug regulatory agencies. Qualified oncology and hematology physicians from established centers can apply to the pharmaceutical company after confirming the availability of a compassionate use program. Once a patient and physician eligibility check is determined, the physician issues an authorized prescription and the patient applies for a government license to import the drug on a named-patient-access program from the Central Drugs Standard Control Organization (CDSCO). On the grant of the license, the company facilitates the delivery of a predetermined and permitted quantity of the drug to the patient. The applying physician of the patient undertakes to follow established protocols and safety standards for the administration of the drug, to provide utilization statements, and to report serious adverse events.

Patients of $\geq 18$ years, with CD22 positive leukemic blasts with no prior history of SOS and having either morphological or molecular persistence of disease, received IO. Patients who received a minimum of one full cycle of IO were included for evaluation. All patients received IO as per a recommended fractionated dose schedule of $0.8 \mathrm{mg} / \mathrm{m}^{2}$ on day $1,0.5 \mathrm{mg} / \mathrm{m}^{2}$ on days 8 and 15 in a 21 - to 28 -day cycle. ${ }^{11}$ From the second cycle onward, if patient was in Complete Remission/Complete Remission with incomplete count recovery, IO was given at a dose of $0.5 \mathrm{mg} / \mathrm{m}^{2}$ on days 1,8 , and 15 of a 28-day cycle. Disease response assessment was done after every two cycles of therapy. Morphologic complete remission was defined as (M1) with $<5 \%$ blasts on bone marrow aspirate, M2 with 5 to $20 \%$ blasts and M3 as more than $20 \%$ blasts. Flow cytometry-based MRD measurement was determined..$^{13}$ The Common Terminology Criteria for Adverse Events (CTCAE v5.0) was used to grade toxicities during and for 30 days post-IO therapy. ${ }^{14}$ Those patients who underwent HCT, adverse events during and post-HCT were noted. Descriptive statistics were employed and the primary endpoint of analysis was complete response. The data collection and analysis has followed the recommendations of the Helsinki declaration of 1964 and amendments thereafter, and our institutional review board provided a waiver for this study.

\section{Results}

Eight patients were eligible for compassionate access and seven patients were evaluable, as one patient with prolonged severe thrombocytopenia and prior bleeding died due to an intracranial hemorrhage in the first week of cycle 1. Patient characteristics are detailed in - Table $\mathbf{1}$. Two patients had morphological disease persistence while five had MRD persistence. Barring the first dose, all patients received this therapy in the outpatient service. Details of individual patient, IO therapy received, and outcomes are documented in - Table 1 .

Of the seven evaluable, all patients achieved deeper remissions and six (85.7\%) were in MRD-negative status. All patients post-IO were eligible for transplant at best response, only four patients (57\%) proceeded to Allo-HCT due to financial constraints and logistics. In the post-HCT setting, two patients are alive and in remission after 2 years and 4 months, respectively, one patient developed grade-IV SOS and died, the fourth patient (Ph + ALL T315I mutated) developed relapse by $\mathrm{D}+43$ and died thereafter. Among the three non-HCT patients, one patient (persistent MRD, post-IO) developed progressive disease and died. The remaining two received post-IO maintenance ALL therapy (vincristine, dexamethasone, methotrexate, and 6-mercaptopurine). They are alive and in remission at last follow-up. One of the two patients required modification in maintenance therapy due to chronic liver disease (Child-Pugh B, hepatitis-B related). At a median follow-up duration of 9 months (4-27.6 months), four (57\%) patients are alive and maintaining remission.

IO monotherapy was relatively safe and well-tolerated. No infusional toxicities were observed. Neutropenia of grades III and IV was seen in three patients (first cycle) and hepatic dysfunction (transaminitis) of grades III and IV in two patients. Two patients developed SOS post-HCT. A disproportionate rise in hemoglobin level was seen in three patients who received a minimum of two cycles of IO $(\boldsymbol{-}$ Fig. $\mathbf{1})$, this is an observation not evaluated in detail which warrants further exploration.

\section{Discussion}

In the subset of nonresponding B-cell ALL, use of novel therapies holds the promise of cure by achieving $\mathrm{CR}$ with negative 
Table 1 Inotuzumab Ozagamycin (IO) treatment and outcomes

\begin{tabular}{|c|c|c|c|c|c|c|c|}
\hline Characteristic & UPN1 & UPN2 & UPN3 & UPN4 & UPN5 & UPN6 & UPN 7 \\
\hline Age/sex & $21 / \mathrm{F}$ & $22 / \mathrm{M}$ & $51 / \mathrm{M}$ & $27 / \mathrm{F}$ & $33 / \mathrm{M}$ & $29 / F$ & $23 / \mathrm{M}$ \\
\hline Prior regimens* & $\begin{array}{l}\text { 1. BFM-95 } \\
\text { 2. HyperCVAD } \\
\text { 3. BVD }\end{array}$ & $\begin{array}{l}\text { 1. ICICLE } \\
\text { 2. HyperCVAD } \\
\text { 3. BMAD }\end{array}$ & $\begin{array}{l}\text { 1. BFM-90 } \\
\text { 2. HyperCVAD } \\
\pm \text { bortezomib }\end{array}$ & $\begin{array}{l}\text { 1. BFM-95 } \\
\text { 2. HyperCVAD } \\
\text { 3. BED }\end{array}$ & $\begin{array}{l}\text { 1. BFM-90 + } \\
\text { dasatinib } 2 . \\
\text { CLOVE }\end{array}$ & $\begin{array}{l}\text { 1. BFM-2002 } \\
\text { 2. HyperCVAD } \\
\text { 3. BED }\end{array}$ & $\begin{array}{l}\text { 1. ICICLE IR } \\
\text { 2. ICICLE HR } \\
\text { 3. BED + IV } \\
\text { Methotrexate } 3 \mathrm{~g} / \mathrm{m}^{2}\end{array}$ \\
\hline $\begin{array}{l}\text { Significant } \\
\text { comorbidities }\end{array}$ & None & None & $\begin{array}{l}\text { Hepatitis B } \\
\text { core antibody } \\
+\end{array}$ & None & None & None & $\begin{array}{l}\text { Obesity, } \\
\text { hypertension }\end{array}$ \\
\hline $\begin{array}{l}\text { Disease status } \\
\text { pre-IO }\end{array}$ & $\begin{array}{l}\text { MRD positive } \\
(2.05 \%)\end{array}$ & $\begin{array}{l}\text { MRD positive } \\
(0.07 \%)\end{array}$ & $\begin{array}{l}\text { MRD positive } \\
(0.09 \%)\end{array}$ & Not in CR & Not in CR & $\begin{array}{l}\text { MRD positive } \\
(0.17 \%)\end{array}$ & $\begin{array}{l}\text { MRD positive } \\
(0.05 \%)\end{array}$ \\
\hline $\begin{array}{l}\text { Line of therapy } \\
\text { with IO }\end{array}$ & 4th & 4th & $3 r d$ & 4th & $3 r d$ & 4th & 4th \\
\hline $\begin{array}{l}\text { CD22 expression } \\
(\%)\end{array}$ & 91.10 & 94.60 & 46.50 & 68 & 88.90 & 96 & 90 \\
\hline Karyotype & $\begin{array}{l}\text { Normal } \\
\text { karyotype }\end{array}$ & $\begin{array}{l}\text { Normal } \\
\text { karyotype }\end{array}$ & $\begin{array}{l}\text { Normal } \\
\text { karyotype }\end{array}$ & $\begin{array}{l}\text { Normal } \\
\text { karyotype }\end{array}$ & $\begin{array}{l}47 X Y,+X, \\
\mathrm{t}(9,22) \\
(q 34 ; q 11.2)\end{array}$ & $\begin{array}{l}\text { Normal } \\
\text { karyotype }\end{array}$ & Normal karyotype \\
\hline $\begin{array}{l}\text { High-risk cytoge- } \\
\text { netic/molecular } \\
\text { markers }\end{array}$ & Negative & Negative & Negative & None & $\begin{array}{l}\text { BCR-ABL1 } \\
\text { with T315I } \\
\text { mutation }\end{array}$ & Negative & Negative \\
\hline $\begin{array}{l}\text { Number of IO } \\
\text { cycles }\end{array}$ & 4 & 2 & 6 & 3 & 1 & 6 & 1 \\
\hline $\begin{array}{l}\text { Post-IO best } \\
\text { response }\end{array}$ & $\begin{array}{l}C R, M R D \\
\text { negative }\end{array}$ & $\begin{array}{l}C R, M R D \\
\text { negative }\end{array}$ & $\begin{array}{l}C R \text {, MRD } \\
\text { negative }\end{array}$ & $\begin{array}{l}\text { CR, MRD } \\
\text { positive }\end{array}$ & $\begin{array}{l}C R \text {, MRD } \\
\text { negative }\end{array}$ & $\begin{array}{l}C R, M R D \\
\text { negative }\end{array}$ & CR, MRD negative \\
\hline $\begin{array}{l}\text { Infusion } \\
\text { reactions }\end{array}$ & No & No & No & No & No & No & No \\
\hline $\begin{array}{l}\text { Proceeded to } \\
\text { allogeneic HCT }\end{array}$ & Yes & Yes & No & No & Yes & No & Yes \\
\hline $\begin{array}{l}\text { Conditioning } \\
\text { regimen }\end{array}$ & $\begin{array}{l}\text { Flu-TBI } \\
\text { myeloablative }\end{array}$ & $\begin{array}{l}\text { Cy-TBI } \\
\text { myeloablative }\end{array}$ & NA & NA & $\begin{array}{l}\text { Flu-TBI } \\
\text { myeloabla- } \\
\text { tive }\end{array}$ & NA & $\begin{array}{l}\text { Flu-TBI } \\
\text { myeloablative }\end{array}$ \\
\hline Donor type & Haploidentical & MSD & - & - & MSD & - & MSD \\
\hline $\begin{array}{l}\text { Neutrophil } \\
\text { engraftment (d) }\end{array}$ & $\begin{array}{l}\text { Did not } \\
\text { engraft }\end{array}$ & $D+15$ & NA & NA & $D+13$ & NA & $D+15$ \\
\hline $\begin{array}{l}\text { Platelet } \\
\text { engraftment }\end{array}$ & $\begin{array}{l}\text { Did not } \\
\text { engraft }\end{array}$ & $D+13$ & NA & NA & $D+17$ & NA & $D+14$ \\
\hline SOS & Yes, severe & No & NA & NA & No & NA & Yes, severe \\
\hline $\begin{array}{l}\text { Other transplant } \\
\text { morbidities }\end{array}$ & $\begin{array}{l}\text { Mucositis } \\
\text { grade-IV, } \\
\text { sepsis }\end{array}$ & $\begin{array}{l}\text { Mucositis } \\
\text { grade III }\end{array}$ & NA & NA & $\begin{array}{l}\text { Mucositis } \\
\text { grade IV }\end{array}$ & NA & Mucositis grade III \\
\hline $\begin{array}{l}\text { Disease status } \\
\text { post-HCT }\end{array}$ & NA & $\begin{array}{l}\text { CR MRD nega- } \\
\text { tive, } D+28, D \\
+365\end{array}$ & NA & NA & $\begin{array}{l}\text { CR MRD } \\
\text { negative, D } \\
+28\end{array}$ & NA & $\begin{array}{l}\text { CR MRD negative, } \\
D+28\end{array}$ \\
\hline $\begin{array}{l}\text { Subsequent } \\
\text { therapy, post-IO/ } \\
\text { post-HCT }\end{array}$ & - & On follow-up & $\begin{array}{l}\text { Maintenance } \\
\text { therapy }\end{array}$ & $\begin{array}{l}\text { Progression } \\
\text { after } 3 \text {-month } \\
\text { alternative } \\
\text { medicine }\end{array}$ & $\begin{array}{l}\text { Relapse } \\
(\text { day }+47) \\
\text { Ponatinib + } \\
\text { BED }\end{array}$ & $\begin{array}{l}\text { Maintenance } \\
\text { therapy }\end{array}$ & On follow-up \\
\hline $\begin{array}{l}\text { Status at last fol- } \\
\text { low-up (cut-off } \\
\text { November 30, } \\
\text { 2020) }\end{array}$ & Dead & $\begin{array}{l}\text { Alive, in } \\
\text { remission }\end{array}$ & $\begin{array}{l}\text { Alive, in remis- } \\
\text { sion, chronic } \\
\text { liver disease }\end{array}$ & Dead & Dead & $\begin{array}{l}\text { Alive, in } \\
\text { remission }\end{array}$ & Alive, in remission \\
\hline Cause of death & $\begin{array}{l}\text { Transplant } \\
\text { related mor- } \\
\text { tality (SOS) }\end{array}$ & - & - & $\begin{array}{l}\text { Disease } \\
\text { progression }\end{array}$ & $\begin{array}{l}\text { Disease } \\
\text { relapse }\end{array}$ & - & - \\
\hline $\begin{array}{l}\text { Follow-up period } \\
\text { (mo) }\end{array}$ & 6.5 & 27.4 & 27.6 & 6.3 & 5.9 & 13.5 & 4 \\
\hline
\end{tabular}

Abbreviations: GMALL-German Modified ALL TreatmentProtocol; BFM-Berlin-Frankfurt-Munster; ICICLE-Indian Childhood Collaborative Leukaemia Group (IR: Intermediate risk, HR: High risk); BED- Bortezomib-etoposide-dexamethasone; BVD- bortezomib-vincrisitine- dexamethasone; BMAD- bortezomib, mitoxantrone, Peg Asparaginase, dexamethasone; B-HyperCVAD - Bortezomib with HyperCVAD. CR: complete morphological remission; MRD: minimal residual disease

Toxicity: As per CTCAE grading v5.0

Note: Molecular/Cytogenetic panel done in the institute: ETV6/RUNX1, BCR/ABL1, KMT2A(MLL), TCF3(E2A). 


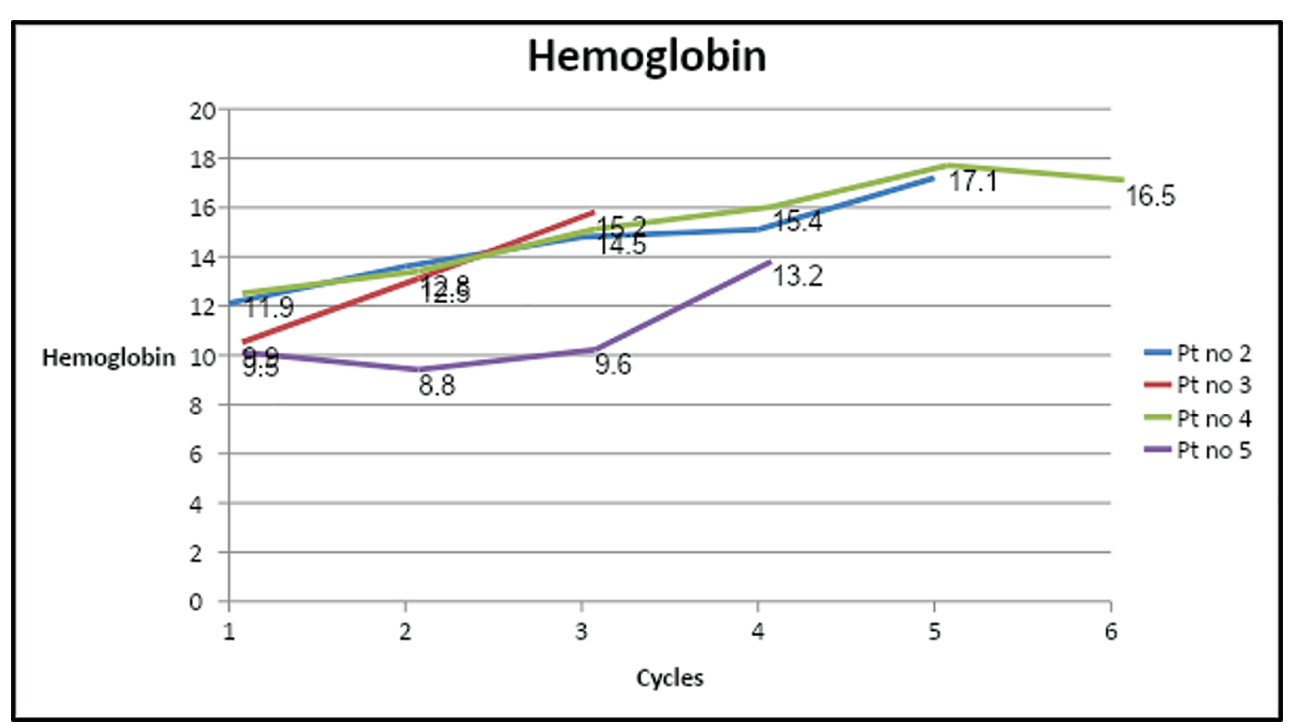

Fig. 1 Unique Patient-identification Number Hemoglobin levels $(\mathrm{g} / \mathrm{dL}$ ) in patients on IO therapy (three patients [UPN 2-3-4] had disproportionate increase after first dose of IO, UPN 5 given as a comparator). IO, inotuzumab ozogamicin; Pt., patient.

MRD followed by consolidation with Allo-HCT. In our setting, IO was well tolerated with manageable grades III and IV nonhematological toxicity and only one patient developed grade-IV neutropenia. All sessions of therapy, with the exception of the first, were administered as an outpatient. This must be seen in comparison to conventional cytotoxic therapies which are intensive and require hospitalization and supportive care. ${ }^{5}$ IO was highly effective in achieving deeper $\mathrm{CR}$ rates in all seven evaluable patients. The response was not dependent on the number of prior regimens received, and possibly the disease burden. Out of seven transplant eligible patients, four proceeded to HCT. This is due to the predominant out-of-pocket nature of cancer treatment expenditure in India. ${ }^{15}$ With a maximum follow-up period of 27 months, three patients are alive. Three patients died (one due to SOS and two due to relapse). IO was well tolerated in this patient group who were heavily pretreated. Liver dysfunction is noted in IO therapy, two patients developed grade-III transaminitis during treatment (self-remitting) and two patients developed grade-IV SOS post-HCT (one patient had received one cycle of IO and recovered, while the second patient who received four cycles of IO was heavily pretreated and underwent Total Body Irradiation conditioning and died). There were no major infectious episodes or other major organ toxicity while on IO. In the pivotal study, 79 of 164 patients (48.1\%) from IO arm proceeded to HCT; among these patients, 18 of 79 patients (22.8\%) developed SOS. ${ }^{16}$

\section{Limitations and Conclusion}

This series documents the initial experience with a novel targeted immunotherapy of B-cell ALL in a tertiary cancer center. Our study has some important limitations, it is a limited case series with only eight patients. Response rates were promising, possibly due to a lower disease burden among most patients. The disproportionate rise in hemoglobin has not been reported with IO elsewhere. It needs further evaluation and could be reactive. Compared with intensive conventional chemotherapies, IO monotherapy is a feasible outpatient-based alternative with excellent response rates and a bridge to a potentially curative HCT. The role of maintenance therapy post-IO-induced molecular remissions needs further evaluation in the transplant ineligible. IO monotherapy is established in salvage therapy of B-cell ALL and studies using IO in combination therapies and frontline therapy are progressing well. ${ }^{17-19}$ Once available in India, it would benefit the Indian clinicians to conduct a prospective registry of patients receiving approved novel targeted therapies in ALL.

\section{Ethics Approval}

Tata Medical Center, Institutional Review Board (TMC-IRB) Ethics waiver number: EC/WV/TMC/47/20.

\section{Authors' Contributions}

Concept and design: V.S.R., R.N., and M.C.

Literature search: V.S.R. and K.M.

Clinical studies: V.S.R., S.J.B., J.K., R.N., M.C., K.M., and M.R. Laboratory studies: D.K.M., N.A., and M.P.

Data acquisition, data analysis: K.M., M.G., and V.S.R.

Manuscript preparation: V.S.R. and K.M.

Manuscript editing: R.N. and M.C.

Manuscript review: V.S.R., K.M., S.J.B., J.K., D.K.M., N.A., M.P., R.N., and M.C.

Guarantors: D.K.M. and M.C.

\section{Funding}

None.

\section{Conflict of Interest}

V. K.S. reports advisory fees (institutional) and nonfinancial Institutional support from PFIZER, Institutional grants and nonfinancial support from INTAS Pharmaceuticals, Institutional grants from NATCO Pharmaceuticals, 
Institutional grants from ROCHE, Institutional grants from BMS, Institutional grants and nonfinancial support from CIPLA Pharmaceuticals, Institutional grants from EMCURE, personal fees (institutional) from ASTRA ZENECA, nonfinancial institutional support from Dr. Reddy's Laboratories, outside the submitted work. Other authors declare no relevant conflicts of interest with respect to the submitted work.

\section{Acknowledgments}

The authors thank Pfizer India for extending the country wide named patient basis compassionate access program of inotuzumab ozogamicin to the patients of Tata Medical Center, Kolkata, West Bengal, India. The authors acknowledge Ms. Sutapa Chatterjee and Mr. Sayak Choudhuri for the support received in data collection.

\section{References}

1 Terwilliger T, Abdul-Hay M. Acute lymphoblastic leukemia: a comprehensive review and 2017 update. Blood Cancer J 2017;7(6):e577

2 Kantarjian H, Thomas D, O'Brien S, et al. Long-term follow-up results of hyperfractionated cyclophosphamide, vincristine, doxorubicin, and dexamethasone (Hyper-CVAD), a dose-intensive regimen, in adult acute lymphocytic leukemia. Cancer 2004;101(12):2788-2801

3 Thomas X, Boiron JM, Huguet F, et al. Outcome of treatment in adults with acute lymphoblastic leukemia: analysis of the LALA-94 trial. J Clin Oncol 2004;22(20):4075-4086

4 Gökbuget N, Stanze D, Beck J, et al; German Multicenter Study Group for Adult Acute Lymphoblastic Leukemia. Outcome of relapsed adult lymphoblastic leukemia depends on response to salvage chemotherapy, prognostic factors, and performance of stem cell transplantation. Blood 2012;120(10):2032-2041

5 Thomas DA, Kantarjian H, Smith TL, et al. Primary refractory and relapsed adult acute lymphoblastic leukemia: characteristics, treatment results, and prognosis with salvage therapy. Cancer 1999;86(7):1216-1230

6 Tavernier E, Boiron JM, Huguet F, et al; GET-LALA GroupSwiss Group for Clinical Cancer Research SAKKAustralasian Leukaemia and Lymphoma Group. Outcome of treatment after first relapse in adults with acute lymphoblastic leukemia initially treated by the LALA-94 trial. Leukemia 2007;21(9):1907-1914

7 Samra B, Jabbour E, Ravandi F, Kantarjian H, Short NJ. Evolving therapy of adult acute lymphoblastic leukemia: state-of-the-art treatment and future directions. J Hematol Oncol 2020;13(1):70

8 Kantarjian HM, DeAngelo DJ, Stelljes M, et al. Inotuzumab ozogamicin versus standard therapy for acute lymphoblastic leukemia. N Engl J Med 2016;375(8):740-753

9 Raponi S, De Propris MS, Intoppa S, et al. Flow cytometric study of potential target antigens (CD19, CD20, CD22, CD33) for antibody-based immunotherapy in acute lymphoblastic leukemia: analysis of 552 cases. Leuk Lymphoma 2011;52(6):1098-1107

10 Marks DI, Kebriaei P, Stelljes M, et al. Outcomes of allogeneic stem cell transplantation after inotuzumab ozogamicin treatment for relapsed or refractory acute lymphoblastic leukemia. Biol Blood Marrow Transplant 2019;25(9):1720-1729

11 Lamb YN. Inotuzumab ozogamicin: first global approval. Drugs 2017;77(14):1603-1610

12 Kebriaei P, Cutler C, de Lima M, et al. Management of important adverse events associated with inotuzumab ozogamicin: expert panel review. Bone Marrow Transplant 2018;53(4):449-456

13 Pawar RN, Banerjee S, Bramha S, et al. Mixed-phenotypic acute leukemia series from tertiary care center. Indian J Pathol Microbiol 2017;60(1):43-49

14 U.S. Department of Health and Human Services, National Institutes of Health; National Cancer Institute. Common Terminology Criteria for Adverse Events (CTCAE) Version 5.0. Available at: https://ctep.cancer.gov/protocolDevelopment/electronic_applications/docs/CTCAE_v5_Quick_ Reference_8.5x11.pdf. Accessed June 8, 2021

15 Selvaraj S, Farooqui HH, Karan A. Quantifying the financial burden of households' out-of-pocket payments on medicines in India: a repeated cross-sectional analysis of National Sample Survey data, 1994-2014. BMJ Open 2018;8(5):e018020

16 Kantarjian HM, DeAngelo DJ, Stelljes M, et al. Inotuzumab ozogamicin versus standard of care in relapsed or refractory acute lymphoblastic leukemia: Final report and long-term survival follow-up from the randomized, phase 3 INO-VATE study. Cancer 2019;125(14):2474-2487

17 Kantarjian H, Ravandi F, Short NJ, et al. Inotuzumab ozogamicin in combination with low-intensity chemotherapy for older patients with Philadelphia chromosome-negative acute lymphoblastic leukaemia: a single-arm, phase 2 study. Lancet Oncol 2018;19(2):240-248

18 Guerra VA, Jabbour EJ, Ravandi F, Kantarjian H, Short NJ. Novel monoclonal antibody-based treatment strategies in adults with acute lymphoblastic leukemia. Ther Adv Hematol 2019;10:2040620719849496

19 McNeer JL, Rau RE, Gupta S, Maude SL, O’Brien MM. Cutting to the front of the line: immunotherapy for childhood acute lymphoblastic leukemia. Am Soc Clin Oncol Educ Book 2020;40:1-12 